\title{
ROSALÍA E OS EMIGRANTES GALEGOS: DA POLISEMIA DA SUAA OBRA E DO SEU MITO NA DIASPORA
}

Xosé M. Núñez Seixas

Ludwig-Maximilians-Universität

München

doi:10.17075/rcsxxi.2014.043 



\title{
ROSALÍA E OS EMIGRANTES GALEGOS: DA POLISEMIA DA SÚA OBRA E DO SEU MITO NA DIÁSPORA
}

\author{
Xosé M. Núñez Seixas \\ Universidade Ludwig-Maximilian, Múnic
}

Nesta sede, non imos incidir sobre cuestións xa abordadas por outros participantes neste volume, e que xa afondaron sobre o tratamento da emigración na obra poética de Rosalía de Castro, e mais da súa contextualización epocal ${ }^{1 .}$ Limitarémonos a tratar sobre a relación entre Rosalía de Castro e os galegos da América, o seu eco e recepción alén mar, e a natureza dese intercambio. Iso supón referirmonos a tres variábeis interrelacionadas: 1) A recepción da obra rosaliana alén mar, 2) o influxo da súa memoria na conformación do imaxinario partillado polos emigrantes galegos, e 3) a elaboración e reinterpretación do que puidésemos chamar mito rosaliano por parte dos diversos axentes institucionais, políticos e culturais que conformaban as colectividades de emigrantes galegos na América dende o último terzo do século XIX e até mediados do século Xx. Pasemos a expor todos estes aspectos devagar.

1 Cf. os relatorios das profesoras Catherine Davies e Pilar Cagiao neste mesmo volume. Igualmente, E. Moure Rojas: "Rosalía y la nostalgia del paraíso: Rosalía y América», en Actas do Congreso internacional de estudios sobre Rosalía de Castro e o seu tempo, Santiago de Compostela, Consello da Cultura Galega / Universidade de Santiago de Compostela, III, 1986, pp. 293-98. 
Como é ben cońecido, a escritora Rosalía de Castro, igual que o seu home, Manuel Murguía, xamais estivo en América en vida. Ao contrario que outros grandes escritores do Rexurdimento, como Manuel Curros Enríquez, non tivo un contacto directo e unha vivencia de primeira man do que era a emigración como protagonista. Por moito que ese contacto fose, no caso de Curros coma no de tantos outros, como «bacharel» ou "plumilla» ou, se se quere, expatriado republicano e máis ou menos galeguista que se dirixiu a América co claro propósito de asumir o liderado dos emigrantes galegos e triunfar como profesional, no seo dunhas colectividades que se vían como a mellor expresión dunha sociedade civil pouco artellada en Galicia e nunhas repúblicas idealizadas como proxectos cívicos en construción ${ }^{2}$.

Foi, emporiso, Rosalía unha observadora aguda do fenómeno migratorio. Mais foino dende a observación empática dos que dende a súa bisbarra natal partían para Cuba, como amosa en varios dos seus poemas máis cońecidos («Prá A Habana!», p. ex., incluído no seu volume de 1880 Follas novas), ou ben para a ceifa en Castela («Castellanos de Castilla, tratade ben aos galegos»...). Engadía á súa interpretación lírica un ton melancólico e reivindicativo asemade, capaz de conxuntar señardade individual e denuncia social colectiva, centrada sobre todo nun radical rexeitamento das que consideraba intuitivamente que eran as causas do fenómeno: a miseria e pobreza do campesińado, a súa falla de recursos que o obrigaban a emigrar levado por un Deus ex macchina. Os labregos parten cara a América (ou cara a Castela), na súa visión desgarrada, levados por unha sorte de destino fatal, guiados por falsas esperanzas, e hanse de enfrontar en poucos meses cunha gran decepción. Talvez o contexto da emigración no Tambre e no Ulla, que ela puido experimentar de preto, influíu nesa visión: bisbarras que foron das pioneiras na emigración ultramarina, logo da crise da industria téxtil rural de mediados do século xx. Rosalía vía no destino dos mozos que ían á Habana un mouro presaxio, e laiaba, ademais, o abandono en que ficaría Galicia («sen homes quedas

2 Cf. X. M. Núñez Seixas, Emigrantes, caciques e indianos. O influxo sociopolitico da emigración transoceánica en Galicia, 1900-1936, Vigo, Xerais, 1998, pp. 140-151. 
/ que te poidan traballar»), pola perda de poboación activa en idade laboral ${ }^{3 .}$ Era unha formulación, polo demais, que se achaba na onda das interpretacións catastrofistas e neomalthusianas que inzaban a Europa da súa época (emigran os máis pobres, levados pola desgraza...), que non presentaba a emigración como unha estratexia individual ou familiar, non tińa conta de redes sociais ou cadeas migratorias, e consideraba de xeito unilateral a emigración como unha desgraza colectiva, visión que o seu home distaría de partillar. Igualmente, como amosa nalgún dos seus relatos en castelán (cf., para mostra, a súa irónica descrición en «El cadiceño», 1866), a poetisa trazou un cadro irónico dos retornados da emigración, nado da observación participante dos emigrantes de retorno (cadiceños) e do seu comportamento externo, e mesmo da súa fachenda, nas feiras padronesas ${ }^{4}$.

Por suposto, Rosalía de Castro non foi a única escritora da época, nin sequera do Rexurdimento, que tratou con sensibilidade o tema da emigración. Algúns dos seus contemporáneos, como o xa aludido Manuel Curros Enríquez, estiveron nun contacto estreito cos emigrantes, partillando con eles inquedanzas e experiencias. Curros, en particular, pasou a última etapa da súa vida (1894-1908) asentado na Habana, e na súa obra transpirábase igualmente unha fonda sensibilidade cara a cuestións universais (señardade do ausente, dor dos que fican no lugar de orixe, causas socioeconómicas do éxodo, desilusión no novo mundo), temas que eran característicos dos procesos migratorios en todo tempo e lugar. Porén, Curros Enríquez significárase politicamente durante a súa etapa americana, tomara partido nas liortas internas da colectividade galega da Habana nun tempo difícil —o da guerra de independencia cubana-, tiña unha biografía político-xornalística comprometida co republicanismo na Península e unha orientación anticlerical. Por iso, a súa pegada era tan intensa como, adoito, debatida. Rosalía, pola contra, posuía unha relativa vantaxe: o seu ton intimista, capaz de apelar e chegar máis fondo ás consciencias, e a lectores moi diversos.

Pola contra, Rosalía era unha imaxe distante e unha referencia máis abstracta, asociada ao compromiso literario, mais non político; e, ademais, fora quen de conxugar ese ton reivindicativo cunha sensíbel recreación dun sentimento inhe-

3 Cf. F. Rodríguez: Análise sociolóxica da obra de Rosalía de Castro, [A Coruña], AS-PG, 1988, pp. 28793; Manuel María, "O tema da emigración na poesía galega», Revista da Comisión Galega Pro-Quinto Centenario, 1 (1989), pp. 131-55.

4 R. de Castro: «El Cadiceño» [1866], en id., Obra completa, Madrid, Akal, 1980, III, pp. 493-504. 
rente a calquera emigrante: a señardade, saudade ou morriña ${ }^{5}$. Facíao con imaxes que incidían, sobre todo, non tanto nos tropos habituais na poesía ibérica ou italiana da época (a omnipresente nai que agarda polo fillo emigrado, p. ex.), senón na vivencia individual do que parte, a súa interpretación subxectiva da ausencia, e a comunón coa súa contorna física e, case diriamos, antropolóxica: as «figueiriñas que prantei», os ríos e mais fontes desa paisaxe... Rosalía daba corpo, así, a unha imaxe case telúrica do vencello do emigrante coa terra que deixa: «cantó al hombre gallego como un anhelo de reintegración a la tierra", lembraba o escritor José Blanco Amor ${ }^{6}$. Isto así mesmo ocorría, como lembraría outro Blanco-Amor moi diferente, Eduardo, en 1939, porque boa parte dos poemas de Rosalía, mesmo dos que non teñen como tema directo a emigración, foron escritos dende o afastamento da súa terra, dende Madrid ou Castela. E a dor da ausencia impregnaba os seus versos, facéndoos sentir próximos aos sentimentos de todos os trasterrados.

Ese feito tamén contribuíu á rápida identificación dos versos rosalianos co que moitos emigrantes sentían, mais non sempre podían verbalizar por si mesmos. Como ben expresaba un colaborador do xornal El Heraldo Gallego de Bos Aires en xullo de 1925, os «tiernos cantos» de Rosalía chegaran ao pobo, lembrándose das súas estrofas «con mística devoción». Pero callaban fondo, sobre todo, no emigrante «forzado a abandonar su tierra, para buscar el pan en suelo extraño, cuando en extraños países, sintiendo el rigor de otros cielos y otros climas, recuerda los verdes campos de su niñez, las rías serenas y los más serenos lagos, las frescas arboledas, la casiña donde nació, el pequeño camposanto donde sus padres duermen, entonces busca el consuelo en las canciones regionales, y de sus labios brotan claras y puras estrofas de Rosalía» ${ }^{7}$. Ninguén expresaría coma Rosalía o desacougo do emigrante ao sentir o desterro do "paradiso rural» que sería a súa terra de orixe ${ }^{8}$ Era a mellor expresión simbólica de «nuestro mundo interior» como emigrantes, afirmaba a revista galeguista porteña Céltiga en $1924^{9}$. "Saudade hecha carne, dolor hecho canto, tierra gallega hecha flor en sus labios»,

5 Cf., por exemplo, a evocación sensibleira da morrińa que fai a partir dos versos de Rosalía Isaac Montenegro: «Morriña», El Heraldo Gallego, 27.11.1927.

6 J. Blanco Amor: «Rosalía Castro y la soledad», Mundo Gallego, 2, xaneiro 1952, pp. 5-6.

7 B. Marcel Porto: «Cumpliose un año más la muerte de Rosalía de Castro», El Heraldo Gallego, 19.7.1925.

8 C. de Castro: «Rosalía de Castro o la añoranza», El Heraldo Gallego, 18.10.1925.

9 «Rosalía de Castro», Céltiga, 2, 12.10.1924. 
resumía igualmente Correo de Galicia de Bos Aires ao lembrar o cabodano da morte da escritora en xullo de 1928 .

Quizais, por iso, por esa gran capacidade empática, a obra rosaliana foi quen de botar fondas raiceiras entre os emigrantes, de obrar un grande impacto emocional en moitos deles: expresaba o que intimamente sentían ou crían percibir, e daba requintada forma literaria a esas mesmas vivencias, como un ausente máis. Rosalía era unha deles, aínda que xamais subira ao barco. E, nomeadamente, era a súa obra en galego a que máis se identificaba con esa valencia, que unía señardade e reivindicación de xeito máis ou menos imbricado. Con todo, non moitos eran os emigrantes que lían a súa obra, polo menos denantes de $1890^{11}$.

A difusión da obra rosaliana en América comezou xa en vida da escritora. Era, de entrada, un reflexo directo da certa distribución das edicións dos seus libros na colectividade galega de Cuba, comezadas polo labor da compañía libreira La Compañía Literaria, estabelecida na Habana da man de Alexandre Chao, quen fora o antigo promotor de La Oliva e El Miño, así como alma mater con Juan Compañel das iniciativas editoriais galeguistas do primeiro provincialismo ${ }^{12}$. Chao emigrara á illa en 1857, a onde chegaría Compañel dezaseis anos máis tarde, e dende alí promovera a publicación La Ilustración Gallega y Asturiana, editada, porén, en Madrid. Igualmente, desempeñou un certo papel no espallamento da obra dos autores do Rexurdimento e editou a obra doutros autores rexionalistas, como o xornalista estradense tamén emigrado na Habana Waldo Álvarez Insua. A iso uníase, ademais, o estreito contacto que o home de Rosalía, Manuel Murguía, mantińa con núcleos activos e máis ou menos prorexionalistas da colonia galega na Habana, que colaborou activa e pecuniariamente na edición do volume III da súa Historia de Galicia (1888) e mais do seu folleto El Regionalismo (1889) ${ }^{13} \cdot \mathrm{Na}$

10 «Rosalía», Correo de Galicia, 13.7.1928.

11 E. López Canedo e A. Gándara Feijoo: «Proyección literaria de la emigración gallega: Nostalgia», Grial, 19 (1968), pp. 44-50; Rodríguez, Análise sociolóxica, pp. 375-76.

12 Cf. X. Martínez González: «Juan Compañel Rivas (1829-1897), alén do editor do Rexurdimento», Grial, 195 (2012), pp. 106-117. Cf. igualmente X. Neira Vilas: Rosalía de Castro e Cuba, Padrón, Patronato Rosalía de Castro, 1992; N. Pérez Rey: «Rosalía de Castro e a emigración: a poeta e Cuba», en A. Angueira (ed.), Rosalía 21, Vigo, Xerais, 2009, pp. 43-49; e C. Pereira-Muro: «Emigración, nacionalismo y literatura: Los gallegos de Cuba en la obra de Rosalía de Castro y Fernando Ortiz», Revista Hispánica Moderna, 61:2 (2008), pp. 119-34.

13 X. M. Núńez Seixas: O galeguismo en América, 1879-1936, Sada (A Coruña), Ediciós do Castro, 1992, pp. 74-76. 
máis nova comunidade galega do Río da Prata, a parella Murguía-Rosalía contou tamén axiña con algúns valedores directos. Nomeadamente, un dos fundadores do primeiro Centro Galego de Bos Aires en 1879, o padronés Manuel Vázquez Castro («Manuel Barros», 1844-1885) ${ }^{14}$, vinculado ao provincialismo serodio e mais ao republicanismo denantes de emigrar a Cuba, primeiro (1862-1871), e a Bos Aires máis tarde, en 1872. Barros mantińa relacións de amizade co casal Castro-Murguía e na Revista Galaica, que fundou naquela cidade (1879-1880), de salientado carácter anticlerical e demócrata, foron publicados xa varios poemas rosalianos, incluídos no volume en castelán En las orillas del Sar. Igualmente, algúns ecos do influxo literario de Rosalía aprécianse nos escritos contemporáneos do propio Barros ${ }^{15}$.

Os recońecementos á súa obra dende a outra beira do océano chegaron xa en vida da escritora, en parte cadrando coa maior difusión que acadou a segunda edición, en 1872, da súa primeira obra en galego, Cantares gallegos. Ao ano seguinte, 1873, Rosalía foi nomeada socia fundadora de honra da Sociedad de Beneficencia de Naturales de Galicia da Habana, feito que ela agradecía cumpridamente nunha nota preliminar do seu libro Follas novas (1880), e atribuía non sen razón á difusión do seu Cantares gallegos alén mar e á súa comunón coa «espresion d'amor pr'a patria ausente» ${ }^{16}$. O libro chegou a ser presentado na biblioteca do selecto Jockey Club de Bos Aires, segundo algún testemuño posterior. Igualmente, á súa popularización tamén contribuíu Curros Enríquez, quen se fixo eco da obra e da figura de Rosalía nalgúns dos seus poemas, como en Aires da miña Tterra, e

14 Manuel Vázquez Castro emigrou con vinte anos á Habana, onde traballou de dependente de comercio, fixo as súas primeiras armas na prensa e foi voluntario contra dos independentistas cubanos. Pouco despois viaxou a Nova Orleáns e Nova York, onde colaborou tamén na prensa, e de alí a Liverpool, despois volveu a Galicia. Emigrou de novo en 1872, desta vez a Bos Aires, onde colaborou na prensa española e arxentina. Foi directivo da Sociedad Española de Beneficencia (1875-76, 1880-83) e presidente da sociedade musical Marina. En 1881, Barros adquiriu o xornal La Nación Española. Catro anos despois morreu prematuramente en Sevilla.

15 Vid. J. A. Durán: Crónicas-3: Entre la mano negra y el nacionalismo galleguista, Madrid, Akal, 1981, pp. 130-31; F. Bouza-Brey: «Manuel Barros, escritor emigrado, amigo de Rosalía y los orígenes de En las orillas del Sar», Cuadernos de Estudios Gallegos, 49 (1961), pp. 218-39. Para mostra dos ecos rosalianos, cf. o seu libro de viaxes e reflexións: M. Barros [M. Vázquez Castro]: Ocios de un peregrino, Bos Aires, Impr. de El Correo Español, 1875.

16 «Os señores da Xunta Directiva e demais individuos que compoñen a Sociedade de Beneficencia d'os Naturales de Galicia n'A Habana», en R. de Castro, Follas novas, Madrid, La Ilustración Gallega y Asturiana / A Habana, La Propaganda Literaria, 1880, s/p. 
despois de morta, no canto III d'O divino sainete (1888), así como nos poemas "A Rosalía» (1891) e «Na tumba de Rosalía» (1904), este último escrito co gallo da súa visita a Galicia, xa residente na Habana, en $1904^{17}$.

Cando chegou a Cuba a nova do falecemento de Rosalía en xullo de 1885, varios foron os órganos da colectividade galega que se fixeron eco do loito pola autora, como o xornal en galego — nado unhas semanas denantes- A Gaita Gallega, que adicou un número especial á súa figura, con contribucións de autores de Galicia e emigrados na Grande Antilla ${ }^{18 .}$ Algunhas publicacións galaicocubanas promoveron xa en 1886 unha subscrición para erixir un mausoleo no cemiterio de Padrón, que rapidamente se canalizaron, en colaboración coa Sociedad Económica de Amigos del País de Compostela, cara á construción ou habilitación dun mausoleo nesta cidade ${ }^{19}$. Igualmente, xa dende comezos da década de 1890, é de salientar o labor que os grupos corais levaron a cabo para espallar a obra rosaliana na propia Galicia, primeiro, e facilitar a súa translación a América de xeito case contemporáneo. Neste aspecto, coma noutros, non sempre se tratou dun proceso unidireccional. Foi adoito na América onde primeiro se interpretou e cantou á escritora, e transplantouse o influxo a Europa, nunha circulación transnacional de estímulos culturais. Púxose así de manifesto na musicalización do poema «Negra sombra», contido en Follas novas, levada a cabo polo compositor Juan Montes xa no ano 1892 e que foi estreada por primeira vez no Gran Teatro da Habana; dende aquela experimentou unha boa acollida nas festas e veladas musicais galegas da emigración. Varios poemas de Rosalía, igual que de Curros e outros autores, serviron de base ás «melodías galegas», de gran difusión en Galicia e América dende $1890^{20}$. Igualmente, outras poesías da autora foron recitadas, musicadas e/ou cantadas por orfeóns e grupos amadores nas festas galegas e nas

17 Cf. C. M. Callón Torres: «A función de Curros no proceso de canonización de Rosalía de Castro», en X. Alonso Montero / H. Monteagudo / B. Tajes Marcote (eds.), Actas do I Congreso internacional «Curros Enríquez e o seu tempo", Santiago de Compostela, Consello da Cultura Galega, 2004, II, pp. 17-52.

18 A Gaita Gallega, 16.8.1885.

19 «Rosalía Castro, suscrición para erigirle un mausoleo en el cementerio de Padrón», Galicia Moderna, 13.12.1886 e 19.12.1886; «El mausoleo de Rosalía», Galicia Moderna, 10.4.1887; U. González Varela: «El monumento a Rosalía Castro», Galicia Moderna, 12.2.1888; «Escritura para la construcción del mausoleo en honor de la insigne poetisa gallega Rosalía Castro de Murguía», Galicia Moderna, 9.9.1888.

20 Cf. M. a P. Alén: «La "edad de oro" de las melodías gallegas (c. 1890-1915)», en VV. AA., Homenaje a José García Oro, Santiago de Compostela, Universidade, 2002, pp. 375-82. 
romaxes galegas e españolas de Bos Aires, A Habana, Montevideo ou Nova York dende finais do século XIX, amais de transmitidas a partir dos anos vinte do século xx por outros medios, como as estacións de radio porteñas, uruguaias ou mexicanas.

Xa en 1897, doce anos despois da morte de Rosalía, celebrouse en Bos Aires un acto na súa memoria, promovido por varios orfeóns, que encargaron a ofrenda dunha coroa floral para a furna da escritora en San Domingos de Bonaval. En xullo de 1901, o xornalista Fortunato Cruces, director do xornal Nova Galicia, promoveu na capital arxentina a constitución dun Ateneo Rosalía de Castro, xunta outros literatos e xornalistas galegos (o xastre, poeta e comediógrafo Avelino Veloso, o xornalista e escritor Manuel Nóvoa Costoya ou a tamén xornalista e poetisa afeccionada María de los Ángeles Vázquez), co obxectivo de recadar fondos para erixir un mausoleo á memoria de Rosalía en Padrón e mais o fin xenérico de espallar as "cousas de Galicia» sen máis especificación, así como actuar como grupo de presión a prol do bo nome do país de orixe. Fins xenéricos e propósitos rexionalistas sans que igualmente impregnaron a actuación da Comisión Curros Enríquez creada poucos anos despois ${ }^{21}$. Malia a brevidade e inconcreción dalgunhas delas, eran iniciativas e homenaxes que contrastaban co certo silencio que imperaba na propia Galicia sobre Rosalía, que só comezou a verse crebado co impacto da edición da súa obra completa en Madrid no ano 1909.

Máis alá da presenza da súa obra en festas e veladas, da frecuencia das mencións a Rosalía na prensa emigrante, das doazóns e iniciativas promovidas dende América para a creación do mito rosaliano, da súa conversión nun lugar de memoria de Galicia e do galeguismo, e da maleabilidade da súa interpretación, a perdurabilidade e profundidade do impacto do mito e do legado rosaliano

21 Nova Galicia, 23.4.1904. 
pódense medir a través de catro indicadores indirectos, máis difíciles de rastrexar metodoloxicamente.

Un, se cadra máis superficial, foi a recorrente presenza de motivos e títulos que evocaban a obra rosaliana nas cabeceiras das publicacións galegas da diáspora, tanto en Cuba coma na Arxentina. Velaí xa, poucos anos despois da morte de Rosalía, o caso do semanario El Río Sar (1893), publicado por breve tempo en Bos Aires, ou da revista cubana Follas Novas, fundada no 1897 cunha certa orientación rexionalista, foron temperáns exemplos desa inspiración rosaliana. Fitos continuados por Airiños d'a miña Terra (A Habana, 1909, se ben é dubidoso se aquí o motivo da inspiración era o homónimo poema de Curros Enríquez), Rosalía (revista publicada en 1937 pola delegación do Centro Galego da Habana na cidade de Santiago de Cuba) ou Airiños (órgano da Casa de Galicia de Bos Aires dende 1944). Algunhas asociacións galegas en São Paulo, A Habana, Barcelona ou Suíza, xurdidas na segunda metade do século xx e que arrebolan o nome de Rosalía de Castro, son exemplos máis recentes.

En segundo lugar, polo non moito que aínda sabemos, as obras da escritora comezaron a estar máis presentes nas bibliotecas das asociacións galegas e, a miúdo, eran case as únicas obras en galego que se podían atopar nos seus estantes. A comezos do século xx, Curros Enríquez laiábase, no seu poema "A espiña» (1903), de as obras de Rosalía e outros escritores galegos non estaren presentes na biblioteca do Centro Galego da Habana, dende Afonso X até Rosalía e Murguía. Porén, ao longo do primeiro terzo do século xx, a súa difusión nesas mesmas bibliotecas aumentou, en primeiro lugar, nas máis modestamente dotadas das sociedades de instrución e asociacións microterritoriais en xeral. Por citar un exemplo cońecido, entre os 288 volumes existentes na biblioteca da Unión Progresista de Salvaterra de Miño na altura de setembro de 1934, os títulos de autores galegos e/ou en lingua galega non chegaban ao $2,8 \%$ do total: contábanse entre estes dúas obras de Rosalía de Castro: El caballero de las botas azules e Follas novas ${ }^{22}$.

En terceiro lugar, dende moi axińa, Rosalía tiña un valor engadido: outorgaba certo status. Estar ou ter estado achegado a ou en contacto con Rosalía (e con Murguía) constituíu con posterioridade unha fonte de prestixio e de certo capital

22 Reglamento y catálogo de libros de la Sociedad Unión Progresista del Distrito de Salvatierra de Miño en Buenos Aires, Bos Aires, s. ed., s. d. [1934]. 
simbólico dentro da colectividade galega. Era o caso do avogado e xornalista da terra de Padrón Fortunato Cruces Angueira (1870-1961), natural de Lestrove e emigrado de moi novo ao Río da Prata, grande alentador do semanario Nova Galicia dende outubro de 1901, de quen se dicía que tiraba boa parte do seu capital simbólico do feito de coñecer de neno a Rosalía e asistir ao seu enterro, pouco antes de emigrar con quince anos con destino á cidade de Rosario ${ }^{23}$. Unha das primeiras publicacións que dirixiu na Arxentina, no 1893, xa citada, levaba xa o expresivo título El Río Sar, xogando probabelmente coa súa propia orixe e co nome do poemario rosaliano ${ }^{24}$. A sombra da terra padronesa, e directa ou indirectamente de Rosalía, habíase estender aínda á obra doutro escritor padronés, Nicasio Pajares, anarquista, republicano e, despois, descarnado e vitriólico retratista, nas súas novelas, do ambiente multiétnico dos países da Prata. Pajares facía aparecer de maneira secundaria a Rosalía nalgunhas caracterizacións e personaxes da súa esperpéntica obra, sobre todo a través das andainas dun fidalgo natural de Lestrove, republicano, librepensador e elevado por el a símbolo dos inmigrantes galaicos, José M. a de la Hermida y Aguasantas —imaxe de José de la Hermida y Castro, curmán de Rosalía de Castro e propietario do Pazo de Lestrove-, quen planeaba fundar unha colonia (Atorrántida) na Patagonia á fronte dun multinacional grupo de atorrantes, isto é, de esmoleiros ${ }^{25}$.

En cuarto lugar, outro indicador, se cadra máis sutil, que nos fala tanto da difusión da obra en Galicia como, probabelmente, da súa posterior re-difusión na América, é o feito de que máis dun emigrante rememoraba, con imaxes tomadas claramente da obra rosaliana (e interiorizadas nunha sorte de habitus) e utilizando os moldes dalgúns dos seus poemas, o que fora a súa partida de Galicia: así, por exemplo, a secuencia «Vendéronlle os bois, vendéronlle as vacas... o carro, as leiras», «Este vaise e aquel vaise» ou «Adiós ríos, adiós fontes»... impregna as evocacións de máis dun emigrante entrevistado na segunda metade do século xx, ou aínda as súas propias autobiografías e memorias. A obra e, sobre todo, as imaxes

23 O xornalista xogaría adoito con esa relación con Rosalía: vid. F. Cruces: «A Rosalía Castro», Almanaque de Galicia, 1 (1909), p. 101.

24 Cf. X. M. Núñez Seixas: «Periodismo, patriotismo “regional” y estrategias de liderazgo: Fortunato Cruces, José R. Lence y los gallegos de Buenos Aires (1900-1936)», en M. A. García Sebastiani (ed.), Patriotas entre naciones. Élites emigrantes españolas en Argentina (1870-1940), Madrid, Editorial Complutense, 2010, pp. 273-305.

25 Cf. N. Pajares: Atorrántida. Novela Romántica, Madrid, Sociedad Gral. Española de Librería, 1929. 
literarias forxadas por Rosalía deviñeron nun espello frecuente no que enxergar as propias experiencias inmigrantes. E, igualmente, convertéronse nun molde moi acaído para transmitilas ${ }^{26 .}$

\section{III}

A recepción acrecentada da obra rosaliana na América foi, en parte, un reflexo da súa entronización no canon dos grandes escritores do Rexurdimento na Galicia metropolitana. Tamén o foi da difusión do seu mito, entendendo tal como a conversión de Rosalía nun símbolo polivalente da galeguidade (ou da identidade galega, en senso xeral) e do galeguismo político (e cultural) asemade. Como xa foi mencionado máis arriba, non se tratou, coma no caso doutros fenómenos da relación cultural entre Europa e América, e entre Galicia e os galegos da América, dun proceso unidireccional. Pois na elevación, relativamente temperá, de Rosalía a mito e símbolo de Galicia tamén tivo moito que ver a intervención proactiva das colectividades de emigrantes, das súas organizacións e elites. Isto non ha sorprender: se un dos axentes difusores dos símbolos, mitos e conmemoracións é o Estado, as monarquías e as Igrexas, os movementos sociais e as institucións ou personalidades investidas dun carisma ou auctoritas especial axudan a forxar eses símbolos, e adoito a espallalos. Tendo en conta que, a comezos do século xx, Bos Aires e A Habana se configuraban de xeito crecente como as cidades máis grandes de Galicia, era lóxico que as diversas institucións (mutualistas, recreativas, de instrución e recreo...) existentes sobre todo na Habana e Bos Aires asumisen un rol sobranceiro e, adoito, protagonista. E, neste senso, a acción dos galegos emigrados foi un factor crucial na codificación, espallamento e fixación dalgúns dos

26 Vid. algúns exemplos en M. Wouters e X. Pantaleón: «O discreto encanto das fontes orais: O proxecto historia oral de Galicia», en C. Barros (ed.), Historia a Debate: Galicia, Santiago de Compostela, Historia a Debate, 1995, pp. 185-92, así como en X. M. Núñez Seixas e R. Farías: «Las autobiografías de los inmigrantes gallegos en la Argentina (1860-2000): Testimonio, ficción y experiencia», Migraciones \& Exilios, 11 (2010), pp. 57-80. Vid. tamén a evocación do sindicalista galaico-arxentino Jesús Mira: «Mis ancestros, vecinos, sindicalistas y vinculaciones gallegas», en R. Farías (comp.), Buenos Aires gallega. Emigración, pasado y presente, Bos Aires, Gobierno de la Ciudad Autónoma de Buenos Aires, 2007, pp. 97-117, ou as memorias familiares, feitas nun pintoresco portuñol, de B. Troncoso Alonso: Memórias de uma Vida. La Herencia no Olvidada, editada por C. Troncoso Castillo, s. l. [Birigüi-São Paulo], Ed. do autor, 1996. 
símbolos máis relevantes do galeguismo, dende o himno ao Panteón de Galegos Ilustres. Durante a fase rexionalista, de feito, a aceptación social deses símbolos fóra do círculo galeguista foi meirande e menos problemática que durante a fase nacionalista (1916 en diante).

Rosalía de Castro contouse, con toda probabilidade, entre os símbolos que con máis forza rebordaron o círculo do galeguismo (ou, se se quere, das minorías mobilizadas rexionalistas a finais do século xIx) e, de maneira case inmediata, converteuse nun símbolo de Galicia ${ }^{27}$ E, polo tanto, asociado a moi diferentes conceptos de Galicia como entidade colectiva, territorial e étnico-histórica, e da súa relación con España. Como é ben sabido, non son os símbolos en si, senón as prácticas sociais que ao seu redor se artellan e as interpretacións que deles se levan a cabo por parte de diversos axentes, o que lles confire un espazo social de influencia, unha función pública e un significado que é partillado por diversos actores, de maneira mudábel e suxeito a evolución. E, neste senso, Rosalía adquiriu cunha gran celeridade unha acusada polivalencia como símbolo. Nesa razón radica tamén, probabelmente, a causa do seu éxito. Pois moitos galegos recibían a súa obra, ou cando menos unha parte dela, aínda que fose de maneira fragmentaria e a través de vías indirectas, dende as lecturas escolares até as composicións recitadas en veladas musicais. E, de maneira especial na emigración, eran quen de identificárense coas vivencias expresadas en clave literaria. Era doado facelo, ademais, con sentimentos de natureza fondamente universal (desarraizamento, saudade, pranto pola infancia perdida, dor polos ausentes...). A calidade dos seus versos axudaba á súa difusión. E neles non só se percibía morriña e saudade. Ademais deses sentimentos podérense incardinar en diferentes narrativas da propia identidade, algúns actores tamén podían escolmar e reparar nos contidos máis reivindicativos da súa obra. Nomeadamente, no que facía á reivindicación (proto)nacional de Galicia, ao seu anticastelanismo tendencial —compoñente que era tamén asumíbel, con todo, na súa formulación pre- ou protopolítica: para moitos españolistas galegos de Bos Aires ou A Habana, eran os casteláns os

27 Cf. R. Villares: «Producir símbolos nacionais», en X. R. Barreiro Fernández e R. Villares (eds.), Os símbolos de Galicia, Santiago de Compostela, Consello da Cultura Galega / A Coruña, Real Academia Galega, 2006, pp. 399-428; igualmente, X. M. Núñez Seixas: «Sobre símbolos y conmemoraciones del galleguismo, 1890-2011», en L. Mees (ed.), La celebración de la nación. Símbolos, mitos y lugares de memoria en el discurso nacional, Granada, Comares, 2012, pp. 191-213. 
culpábeis de levar a América o concepto despectivo de «gayego» e os insolidarios cos seus compatriotas - e mais á súa sensibilidade social e de xénero, expresada neste caso na súa radical empatía co sufrimento das mulleres que no país de orixe agardaban por homes, pais e fillos que xamais voltarían. E moitos outros podían ficar sinxelamente nunha interpretación rexionalista da súa obra, nunha mera dimensión localista que axuntaba patria local ou Heimat (padronesa, mais extrapolábel a calquera outro lugar) con identidade española. Ambas as dúas facetas do fenómeno decorreron de xeito case paralelo, e tiveron como protagonistas actores en boa parte diferentes.

Así, foi dende América, como xa vimos, que xurdiu a iniciativa para que os restos mortais de Rosalía fosen trasladados á igrexa compostelá de San Domingos de Bonaval, enviáronse doazóns para custear o mausoleo funerario que dende entón alberga os seus restos. O cadaleito foi transportado á igrexa o día 25 de maio de 1891, e ía xa envolto cunha bandeira branquiazul, até entón discutida (e aínda o había ser até os anos trinta) por amplos sectores da sociedade galaica, comezando polas colectividades de América. Un dos que portaba as fitas do cadaleito, Joaquín Díaz de Rábago, facíao en representación expresa dos galegos de Cuba, pois con el e coa Sociedad Económica de Amigos del País compostelá relacionarase a revista habaneira Galicia Moderna co gallo da subscrición comezada xa no $1886^{28 .} \mathrm{O}$ acabado de nacer panteón converteuse, polo que sabemos, nun auténtico lugar de peregrinación para intelectuais e dirixentes dos galegos de América de visita en Compostela. Diante do sartego de Rosalía fixéronse fotografar dous plumillas galaico-porteños, o xornalista coruñés José R. Lence, influente director do semanario porteño Correo de Galicia, e o escritor en castelán Xavier Bóveda co gallo da súa visita ao país no verán de 1922, xeira durante a que Lence, antigo maurista e rexionalista moi morno, cońeceu a boa parte da intelectualidade galeguista e experimentou unha fuxidía fascinación polos postulados do novo nacionalismo ${ }^{29}$. O mesmo facían os directivos do Centro Galego de Nova York uns anos despois, coa colocación dunha ofrenda floral aos pés da tumba de Rosalía. Varios centros galegos da América tamén recadaron fondos para subsidiar a erección do monu-

28 Cf. a crónica de A. B. (Alfredo Brañas) en La Patria Gallega, 25.5.1891.

29 Cf. J. Lesta Meis: "La tumba de Rosalía», Correo de Galicia, 8.9.1929. Vid. tamén J. R. Lence: Jornadas de lucha, Bos Aires, E. Menéndez, 1924. 
mento a Rosalía de Castro da Alameda compostelá, que, promovido pola Liga de Amigos de Compostela e sumándose a diversas subscricións en Galicia e América, foi finalmente inaugurado no 1917, e en cuxa iconografía a imaxe do emigrante non ocupa un papel explícito, aínda que si o desempeñaba nalgún dos proxectos presentados ${ }^{30}$. Nalgunhas desas veladas, como nas celebradas en Bos Aires contra 1916, non era infrecuente a representación de obras de teatro en galego, da pluma de escritores afeccionados residentes na Arxentina, e tons reivindicativos da identidade galega que ían alén do habitual nas festas galegas da época ${ }^{31}$. No caso da nova iniciativa posta en marcha para erguer un monumento a Rosalía de Castro na cidade da Coruña, proposta polo ex-alcalde Manuel Casás no 1928 para que figurase a carón de Concepción Arenal —outro gran símbolo, por diferentes razóns, na emigración — e de Emilia Pardo Bazán, os apoios fundamentais xurdiron da colectividade emigrante na Prata, para o que o Centro Coruñés da capital arxentina xa convocou un ambicioso festival en setembro daquel ano ${ }^{32}$. $\mathrm{O}$ posterior monumento á poetisa en Padrón, inaugurado na década de 1950, foi subsidiado polos padroneses residentes no Uruguai, segundo consta no pedestal da estatua, nunha subscrición á que tamén se sumaron os conterráneos residentes en Bos Aires ${ }^{33}$.

$\mathrm{Na}$ América, e nos demais destinos da emigración, Rosalía gozaba ademais dunha indubidábel vantaxe para as comunidades galegas: era unha icona doadamente identificábel dende fóra. E, xa que logo, un indicador de prestixio étnico. Pois a obra rosaliana era tamén coñecida por varios intelectuais arxentinos, uruguaios, brasileiros ou cubanos, que lían, estudaban e citaban a súa obra, considerándoa como un patrimonio universal. O historiador e representante do "primeiro nacionalismo» arxentino Ricardo Rojas vía en Rosalía unha «voz ingenua»

30 Cf. os diferentes proxectos presentados ao concurso público en Vida Gallega, 52 (febreiro 1914). Igualmente, "Cómo surgió la idea del monumento a Rosalía Castro», Diario de Galicia, 25.7.1917, e número especial de El Eco de Santiago, 1917.

31 Vid., por exemplo, M. Castro López: «Nuevos preliminares de asociación gallega», El Eco de Galicia, 10.5.1900, e mais «Pro-suscripción Rosalía de Castro», Nova Galicia, 22.9.1916.

32 «El monumento Rosalía de Castro en La Coruña», Correo de Galicia, 2.9.1928.

33 Cf. M. Gallego Esperanza: «La iconografía de Rosalía de Castro en la escultura pública», Boletín de Estudios del Seminario / Seminario "Fontán Sarmiento» de Hagiografía, Toponimia y Onomástica de Galicia, 14 (1993), pp. 95-100. 
e lírica, mais igualmente un forte acento de crítica social ${ }^{34 .} \mathrm{E}$ algúns escritores, como a uruguaia Juana de Ibarbourou, recibiron un claro influxo da poética rosaliana. Outros, como o poeta arxentino José M. ${ }^{a}$ Castiñeira de Dios (1920), fillo de galegos nado en Ushuaia, afirmaban que o seu interese pola poesía proviña dos poemas de Rosalía de Castro que a súa nai lle recitaba todas as noites antes de adormentar ${ }^{35}$. Houbo igualmente edicións no novo continente dos principais libros en verso da escritora xa entrado o século xx: a cuarta edición de Follas novas, por exemplo, foi realizada en Bos Aires pola editorial Emecé no 1943.

A escritora padronesa non era o único símbolo colectivo dos galegos de América. Outros tiveron eco: dende o Padre Feijoo até a Cruz de Santiago, pasando pola evocación do Apóstolo Santiago ou a invención dun Colombo galego. Mais dende comezos do século $\mathrm{xx}$ incorporouse plenamente a ese conxunto ecléctico de glorias de Galicia invocadas polas elites emigrantes. O nome de Rosalía de Castro, ademais, xeraba, polo menos até o estalido da Guerra Civil española, un certo consenso entre sectores moi diferentes, agás algunhas excepcións (que abranguían os sectores ultramonárquicos españolistas e os socialistas internacionalistas), das colectividades de emigrantes galegos. Púxose así en evidencia co gallo da imposición do nome de Rosalía de Castro a unha rúa porteña a comezos de 1928, iniciativa que se sumaba ás xa existentes rúas Galicia de Bos Aires e de Avellaneda (neste caso xa no 1908), e que xurdira da proposta dun concelleiro e presidente do Concejo Deliberante da Municipalidade de Bos Aires, o oftalmólogo do Centro Galego Adrián Fernández Castro ${ }^{36 .}$

Mesmo os que na esfera pública pasaban por gañar a vida facendo rexouba das inmigrantes galegas, como a actriz Niní Marshall, filla de asturianos (galegófonos de San Tirso de Abres), afirmaba ler a Rosalía e mais a Curros Enríquez para se documentar sobre a mentalidade das súas personaxes, neste caso para encarnar a mucama Cándida Loureiro Ramallades, a famosa Cándida, nas súas audicións radiais e mais nas súas interpretacións cinematográficas ${ }^{37}$. Doutra banda, algúns

34 R. Rojas: Retablo español, Bos Aires, Losada, 1938, pp. 346-47. Cf. tamén as observacións de Ricardo Arlt no seu libro de 1935 Aguafuertes gallegas, Sada (A Coruña), Ediciós do Castro, 1997.

35 Cf. M. Guidotti: «El imaginario de la inmigración española (los "gallegos”) en el sainete argentino», Tese de doutoramento, Universidad de Salvador, Bos Aires, 2010, p. 101.

36 Vid. «Calle Rosalía Castro», Correo de Galicia, 1.1.1928, e "Un homenaje a Galicia», Nova Galicia, 24.1.1928, p. 1.

37 N. Marshall e S. D’Anna: Nini Marshall: Mis memorias, Bos Aires, Moreno, 1985. 
sainetes crioulos cuxos protagonistas tamén eran galegos incluían o recitado dalgunha poesía de Rosalía por parte dos personaxes, polo menos nos exemplos de pezas ou autores máis sensíbeis, e mellor informados, cara á cultura galega e á imaxe dos inmigrantes galegos. Era o caso do uruguaio Alberto Weisbach no seu sainete Farruco (1921) ${ }^{38}$. Rosalía chámase, precisamente, unha das protagonistas femininas, e galaica, da peza ;Gallego lindo! de José A. Bugliot e Rafael J. de Rosa, estreada en xullo de 193139. E un título de evocacións inequivocamente rosalianas, Airiños da miña Terra, tiña o sainete de Alberto Novión estreado no 1924, en cuxo acto primeiro podemos atopar unha escena en que é máis que evidente a intertextualidade coa poética da autora galega:

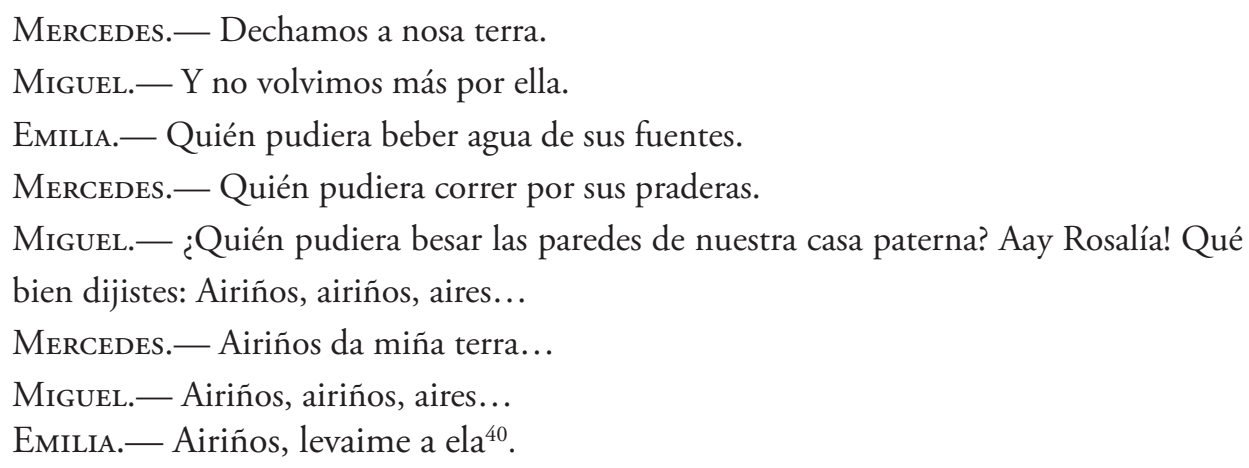

Tamén polo vieiro do teatro popular porteño, polo tanto, podía achar a obra rosaliana unha indirecta difusión. E moitas destas obras eran representadas nos festivais das propias asociacións galegas.

Porén, tamén era na América onde o mito de Rosalía se prestaba a interpretacións para nada conflitivas co relato da españolidade, e contribuía a maiores a conferirlle organicidade e forza evocativa. Sendo galegos máis do metade dos españois do Río da Prata, e máis dun terzo dos residentes na Perla das Antillas, difícil era trasladar á diáspora o castelanocentrismo tendencial do discurso nacionalista español. E, doutra

38 A. Weisbach: «Farruco», La Escena, 145 (7.4.1921).

39 J. A. Bugliot e R. J. de Rosa: «iGallego lindo!», La Escena, 703 (17.12.1931).

40 A. Novión: "Airiños da miña Terra», La Escena, 310 (1924). Noutros casos era a obra de Curros Enríquez a parafraseada. Sobre o teatro de Novión, autor que amosou unha gran sensibilidade cara aos inmigrantes, vid. O. Pellettieri: Alberto Novión: La transición al grotesco criollo, Bos Aires, Eudeba, 2007. 
banda, mesmo na Península ese discurso españolista estaba máis disposto a aceptar unha lectura baseada nunha interpretación prepolítica da «pluralidade» do que adoito se pensa. Así, dende 1899, tiveron lugar con relativa regularidade as chamadas Veladas Gallegas, reunións artístico-literarias e de debate político nas que a elite selecta da colectividade galega (profesionais liberais, profesores, grandes comerciantes e industriais, representantes do Consulado español e algúns xornalistas) se daba cita na consulta do prestixioso médico compostelán Ángel Anido, chegado ao país no 1882, presidente da Asociación Patriótica Española nos anos do cambio de século. No decurso desas veladas escoitaban música galega e recitaban producións inéditas en galego de escritores residentes en Bos Aires. De paso, un mantedor lía discursos patrióticos nos que se reverdecían os fastos do perdido imperio español, mentres unha estatua de Rosalía de Castro enfeitada coa bandeira galega presidía a xuntanza. A prematura morte de Anido no 1901 deu cabo a estas formas de sociabilidade ${ }^{41 .}$ Na súa necrolóxica, a revista porteña Caras y Caretas lembraba a súa devoción por Rosalía, así como que organizara unha velada para financiar unha estatua á poetisa ${ }^{42}$.

O contido galeguista, neste caso, semellaba estar subordinado á narrativa do nacionalismo español: construíase e recreábase identidade española a través da rexión, mediante un nacionalismo rexionalizado no que non se reivindicaba descentralización ou autonomía. E esa lectura tivo certa continuidade. Na segunda metade dos anos vinte, o concurso de composicións poéticas convocado polo sobranceiro xornal da colectividade española, o Diario Español, aliñado na altura coa ditadura de Primo de Rivera e coa colaboración da protofascista Liga Patriótica Argentina, incluía paradoxalmente un premio (no número 19) destinado ao «mejor estudio acerca de la obra poética de Rosalía de Castro», a carón de composicións adicadas a Colombo, á raína Isabel a Católica, ás «glorias de España» ou «el soldado español» ${ }^{43}$. Nas páxinas da revista da porteña Asociación Patriótica Española Hispania (logo rebautizada como España) tamén se reproduciron, ás veces, algúns dos poemas rosalianos ${ }^{44}$.

\footnotetext{
41 Vid., por exemplo, a crónica da primeira destas veladas, celebrada en maio de 1899 e á que asistiron 49 notábeis da colectividade acompañados das súas donas, en «Inauguración de las veladas gallegas», El Eco de Galicia, 10.6.1899. Igualmente, a evocación do xornalista Fortunato Cruces en Nova Galicia, 14.11.1929. 42 «Necrología», Caras y Caretas, 15.6.1901.

43 «Digna conmemoración del Día de la Raza», El Heraldo Gallego, 31.5.1925.

44 Cf. A. Duarte: «España en la Argentina. Una reflexión sobre patriotismo español en el tránsito del siglo XIX al XX», Illes i Imperis, 7 (2004), pp. 177-99.
} 
A carón desa interpretación, os sectores galeguistas tamén arrebolaron, como era lóxico e esperábel, o nome e o mito de Rosalía. E viron nela todo o que os sectores españolistas ou rexionalistas mornos non querían ou podían recoñecer: o seu anticastelanismo varudo en "Castellanos de Castilla», a súa paixón e sensibilidade feminina (nalgúns casos), a súa defensa proactiva da identidade galega, o eco social comprometido da súa interpretación da emigración, que encaixaba moi ben coa visión preponderante dentro do galeguismo político de entreguerras. Era, ademais, un símbolo a partir do cal construír consensos máis amplos. Deste xeito, se os galeguistas porteños máis radicais da década de 1920 se inspiraban en Eduardo Pondal e elixiron mesmo adoptar o seu nome en homenaxe (Sociedade d'Arte Pondal, Sociedade Nazonalista Pondal), vendo nos rexos versos de resonancias célticas do bardo un maior acento reivindicativo, os galeguistas "posibilistas», procedentes do primeiro núcleo da Irmandade Nazonalista Galega en Bos Aires e que se integraron dende 1925 na Federación de Sociedades Gallegas, Agrarias y Culturales (FSG), fundada catro anos denantes, entre eles o escritor Eduardo Blanco-Amor, o antigo sindicalista Ramón Suárez Picallo e mais o mestre Antón Alonso Ríos, promoveron varias iniciativas en nome de Rosalía, co obxecto de tecer complicidades cos sectores esquerdistas da colectividade que receaban do galeguismo. Comezaron cunha homenaxe celebrada en xullo de 1925, nos salóns do Orfeón Español e perante unha abondosa concorrencia, para conmemorar o 40 aniversario da morte da poetisa ${ }^{45}$. Esas angueiras tiveron continuidade nunha campaña a prol da adquisición da casa de Rosalía en Padrón, ao chegar a nova de que podería ser vendida a mans particulares, entre mediados de 1926 e 1928, co fin de a converter nunha sorte de casa-museo, pero tamén en lugar de memoria de Galicia e das súas colectividades emigradas. Antón Alonso Ríos, un dos promotores da iniciativa, escribía así que a casa de Rosalía había devir «nuestro Hogar nacional», unha sorte de santuario laico onde o pobo galego rendería homenaxe e culto non só á memoria da poetisa, senón tamén «a la única verdadera Divinidad gallega: "a nosa Terra”", agardando dela «un solo milagro: el maravilloso milagro de la cultura gallega ${ }^{46}$. A FSG celebrou así un novo festival de homenaxe solemne a Rosalía de Castro, e varias sociedades de instrución nas que

45 Cf. a crónica, non exenta de críticas a Eduardo Blanco-Amor pola súa interpretación excesivamente "política» da obra de Rosalía nun acto que se pretendía que englobase a todos os sectores da colectividade galega, en Correo de Galicia, 19.7.1925.

46 A. Alonso Ríos: «La nacionalización de la casa de Rosalía: Una idea loable», Céltiga, 10.12.1926. 
os galeguistas tiñan algunha influencia organizaron igualmente veladas, matinées danzantes e romarías para recadar fondos co obxectivo de que o inmoble (a actual Casa da Matanza) pasase a propiedade pública. Nesas festas, adoitaba ser maioritario o teatro e mais a música galegas e en galego, e os dirixentes galeguistas da Federación acostumaban recitar poesías de Rosalía de Castro e pór o punto final, xunto con autores teatrais galegos como Jesús Seijo e G. Fernández Couto ${ }^{47}$. A campaña non cesou, malia chegar a Bos Aires a nova de que as catro deputacións provinciais galegas e mais o Concello da Coruña acordaran adquirir o inmoble coa intención de o converter en museo, trocándoo en «Santuario Emocional de la Raza»48.

Logo de dous anos, os galeguistas porteńos tiveron que constatar que a forza do mito non era abondo para facer que os emigrantes rañasen abondo o peto. Así e todo, xa na altura estaba consagrado un vocabulario de referencias místicas agora secularizadas, que falaban da identificación entre Rosalía e a patria, adoito definida como unha matria que era santa asemade: a resemantización da poetisa como unha sorte de «santa da nación» galega tería gran perdurabilidade, e amosaba, ás claras, a consolidación da codificación simbólica da súa figura como corporeización feminina da nación (ou nacionalidade), compatíbel con outras representacións (a da República, por exemplo). De maneira paralela, rexistráronse outros recoñecementos simbólicos a escala local ou comarcal, mais promovidos dende a emigración. A sociedade Hijos de Silleda acordou dar o nome de Rosalía de Castro a unha das dúas escolas sostidas coas contribucións dos seus socios no seu concello natal, coa xustificación de as súas poesías constituíren «la más alta consagración del sentimiento de nacionalidad gallega [...] por estar escritas en idioma propio, son el signo de una cultura autóctona ${ }^{\text {"49 }}$. Non foi a única sociedade de instrución que puxo o nome de Rosalía aos estabelecementos escolares sostidos en Galicia, mais si quizais a que dotou ese nome dun significado máis ou menos nacionalista. Doutra banda, a obra da poetisa adoitaba ser un dos piares do ensino da lingua e da literatura galega nas non moitas escolas dos americanos que incluían algunhas horas (polo xeral, os sábados) adicadas a esas materias.

47 Por exemplo, o festival da Unión Estradense en outubro de 1927: cf. Correo de Galicia, 30.10.1927.

48 Correo de Galicia, 1.12.1926.

49 «La Sociedad Hijos de Silleda celebra su XX aniversario», Céltiga, 10.8.1928. 
Cómpre salientar, porén, que non sempre a admiración partillada pola poesía de Rosalía levaba a varias daquelas sociedades a outorgar un papel relevante ao idioma galego nas súas actividades, a introducilo como materia ou como lingua vehicular nas escolas sostidas en Galicia, ou mesmo a considerar que o galego rebordase o nivel diglósico, como lingua de xéneros literarios menores, intimistas ou recluída á conversa informal, e precisamente por iso vehículo máis acaído de expresión da saudade e da morriña, asociada ao medio rural de procedencia do país natal. Así lle aconteceu nunha ocasión ao escritor Eduardo Blanco-Amor, grande admirador e coñecedor, polo demais, da obra de Rosalía, cuxos versos ecoaban nos seus Romances galegos publicados no 1928 en Bos Aires, sobre todo nos poemas de inspiración popular da primeira parte do mesmo («Os nocturnos»). Segundo o seu propio testemuño, cando o ourensán foi convidado pola mesma época a dar unha palestra sobre Rosalía de Castro na velada organizada por unha asociación galega, foi apupado por empregar o galego, e recriminado polo presidente da institución... ${ }^{50}$.

\section{IV}

Durante a década de 1930, e máis aínda durante os tres anos da Guerra Civil española, pódese afirmar que o mito rosaliano perdeu pulo reivindicativo na mesma medida en que se asentou progresivamente nun panteón de divindades secularizadas que representaban a Galicia, a carón da pedagoga e penalista Concepción Arenal e, en certo senso, do poeta emigrante Curros Enríquez. Rosalía sobranceaba entre eles pola súa forza emotiva e pola súa condición de matria, de representación corpórea da nación. A súa forza protestataria, en parte, tamén devalou porque outros mitos, personaxes ou lugares de memoria de teor máis combativo ocupan o lugar noutrora tamén reservado a ela: velaí o caso do mariscal Pardo de Cela, por exemplo, cuxa idealizada figura se estendeu entre os medios galeguistas da emigración dende finais da década de 1920 — principiando

50 Reproducido en V. F. Freixanes: Unha ducia de galegos, Vigo, Galaxia, 1982 [2a], p. 96. Logo de comezar a pronunciar a súa palestra en idioma galego, o público apupouno e guindou obxectos ao escenario, e o presidente da entidade achegóuselle para lle dicir «que que pensaba que eran eles, se pensaba que eran uns desgraciados, uns incultos, unhas bestas que non sabían falar coma todo o mundo». A reacción de Blanco-Amor foi converter a palestra sobre Rosalía nun mitin sobre Rosalía e a identidade galega. 
pola recepción da obra de teatro $O$ mariscal (1926), de Ramón Cabanillas e Villar Ponte, e seguindo polas homenaxes tributadas pola Semana Gallega de 1926 a Pardo de Cela e mais a promoción do 17 de decembro como efeméride patriótica alternativa ao 25 de xullo por parte dos galeguistas do Río da Prata. Así e todo, a Rosalía volvíase sempre de xeito recorrente, nomeadamente cada mes de xullo, ao se lembrar o aniversario da súa morte, por moito que a súa evocación resultase ser, adoito, un tanto rutineira.

Comezada a Guerra Civil española, foi un político procedente da emigración, Ramón Suárez Picallo, quen concibiu a idea de que os integrantes das Milicias Gallegas recrutadas en Madrid no verán do 1936, iniciativa galeguista axiña asumida e protagonizada polos comunistas, adoptasen como símbolo un poema de Rosalía $^{51 .}$ No decurso da mobilización a prol da República en guerra que protagonizou boa parte da colectividade galega de Bos Aires, e da posterior en apoio dos refuxiados galegos aínda varados nos campos de internamento franceses, a FSG, reunificadas agora as súas dúas pólas galeguista e socialista, viuse obrigada a adiar a conmemoración do centenario de Rosalía en febreiro de 1937. Como expresaba daquela o voceiro federal Galicia, en termos propios dunha case-relixión política, a liberación do «Santo Sepulcro da nosa Santa» habería ir parella á liberación de Galicia da pouta fascista e recentralizadora, e a celebración de Rosalía habería asociarse á vitoria final, nunha sorte de palinxénese ${ }^{52}$. Pola contra, o centenario si foi celebrado na Habana, a iniciativa sobre todo da revista Cultura Gallega e con participación sobranceira dun exiliado galeguista, Xerardo Álvarez Gallego ${ }^{53 .} \mathrm{O}$ Centro Galego de Bos Aires, que daquela (e até as disputadas eleccións de outubro de 1938, gańadas por unha candidatura unitaria prorepublicana) tentaba manter unha difícil neutralidade perante os dous bandos enfrontados na guerra de España, si procedeu a conmemorar timidamente o centenario de Rosalía e reproduciu de maneira aséptica varios dos seus poemas nun número do seu voceiro social, Galicia. Con todo, a diferenza do pasado, a común invocación á poetisa xa non servía para crear motivos de unidade. Si lle servía ao Centro Galego da Habana, tamén na altura tentando manter a neutralidade na contenda, que dende

51 Carta de R. Suárez Picallo a Eduardo Blanco-Amor, Madrid, 17.8.1936 (Biblioteca da Deputación Provincial de Ourense, fondo Blanco-Amor).

52 Vid. «Rosalía Castro», Galicia, 28.2.1937.

53 X. Neira Vilas: A prensa galega de Cuba, Sada (A Coruña), Ediciós do Castro, 1983, p. 43. 
febreiro de 1937, coincidindo coa celebración do centenario do nacemento da autora, publicou a través da súa delegación en Santiago de Cuba varios números dunha revista mensual ilustrada, de nome Rosalía, así titulada «en honor de la excelsa poetisa gallega», co obxecto de tratar de temas "científicos y literarios», con escasa presenza do galego e sen alusións á loita que tiña lugar na Península ${ }^{54 .}$ Un ton máis comprometido, incidindo máis nos contidos sociais da obra rosaliana, revestiu o número adicado pola revista montevideana Alma Gallega, voceiro da republicana Casa de Galicia da capital uruguaia, co gallo do centenario da morte da escritora.

A restauración triunfante de Rosalía na súa terra, da man do galeguismo e da causa da República, non puido ter lugar da maneira en que degoxara BlancoAmor. Despois do triunfo de Franco, cumpría converter a poetisa nun símbolo anovado de esperanza e de resistencia. A FSG resolveu celebrar en xullo de 1939 unha xeira de actos de homenaxe a Rosalía de Castro, convertida agora nun mito mobilizador máis posto ao servizo da causa republicana e galeguista. A santa, agora renomeada cantora do pobo que unía galeguismo e xustiza social, ao estilo do que sinalaría a escritora española exiliada Luisa Carnés dende México5, había sinalar o camiño das liberdades democráticas e do autogoberno para unha Galicia libre. No festival, celebrado no Teatro Avenida, interviñeron o líder do galeguismo na cidade de Bos Aires Rodolfo Prada, o exiliado galeguista de primeira hora Xosé Núnez Búa e o escritor Eduardo Blanco-Amor, mentres grupos musicais e folclóricos executaban diversas pezas, e (como era usual nas festas galegas de Bos Aires, e talvez para subliñar o carácter non antiespañol e igualmente republicano do acto) unha peza flamenca. O programa de actos tamén incluíu unha ofrenda floral realizada na rúa Rosalía de Castro, con adhesión de varias sociedades de instrución, presentes cos seus estandartes ${ }^{56}$.

Ese mesmo ano 1939, a Federación editaba unha antoloxía de poemas de Rosalía, encargada dous anos antes a Blanco-Amor. Este último salientaba no seu

\section{Idem, pp. 76-77.}

55 A madrileña salientaba así que Rosalía estabelecera «un nexo auténtico entre el escritor y el pueblo», apropiándose das súas inquedanzas (R. Carnés: Rosalía de Castro. Raíz apasionada de Galicia, México DF, Eds. Reus, 1945, p. 94 (sería reeditada outra volta en México, Alejandro Finisterre ed., 1964, e como separata da revista Compostela. Revista de Galicia, 1, 1967).

56 Cf. o documental mudo do acto, restaurado polo Centro Galego de Artes da Imaxe, en http://www. consellodacultura.org/rosalia2013/recursos.php. 
limiar a identificación de Rosalía cos trasterrados, polo feito de os seus poemas seren sempre "polémicos, de contraste, es decir, obra de emigrante», xa que foran escritos en Castela para fuxir «de la muerte que la rodeaba con la plástica de un paisaje imposible y de una raza intratable». Blanco-Amor tracexaba un implícito paralelismo entre a morte, consumida polo cancro e o sufrimento, de Rosalía e a situación do país natal que xemía baixo a pouta franquista: «la gran ala de sombra que llega devorando, en noche anticipada, los perdidos horizontes, me invita a pensar en la muerte de la Santa». Mais do mesmo xeito que a obra da escritora sobrevivira e era inmorredoira, Galicia tamén o sería. A antoloxía, de acordo coa tónica política imperante naquela altura na FSG, tentaba implicitamente unir galeguismo con tradición republicana, incluíndo nela o limiar á primeira edición de Follas novas, obra do finado republicano español Emilio Castelar ${ }^{57}$. Con todo, algúns dirixentes de tendencia socialista da Federación seguían a profesar, coma vinte anos denantes, un teimudo desprezo pola figura de Rosalía, á que vían como choromiqueira expresión dunha morriña que adurmiñaría a consciencia social e revolucionaria do pobo galego, fronte á poesía civil e rebelde de Curros Enríquez, por quen sentían meirande predilección - e outorgaran o seu nome ao Ateneo creado no seo da FSG no 1941—, aínda que máis dun sentía, sinxelamente, rexeitamento por toda expresión literaria en lingua galega. Un deles, o socialista ourensán Quirino Rodríguez Martínez (1861-1941), botou nabos ao escenario cando Eduardo Blanco-Amor falou de Rosalía, segundo rememoraría o escritor anos despois. E outro, Rogelio Groba, laiaba no 1940 dende o xornal Galicia da Federación que ao chegar «la fecha de nacimiento de una Rosalía de Castro» se lle adicase unha atención ao seu xuízo desmesurada, nun momento en que todas as enerxías se habían concentrar en combater o fascismo. O seu artigo, porén, soergueu unha certa poeira dentro da Federación ${ }^{58}$.

Pola contra, a utilización de Rosalía como mito dun españolismo rexionalizado diminuíu considerabelmente, se non desapareceu de todo, a partir de xullo de 1936, malia no bando insurxente e na propia Galicia haber quen defendese de

57 E. Blanco-Amor: «Palabras breves sobre Rosalía de Castro», en R. de Castro, Poemas galegos, Bos Aires, FSG, 1939, pp. III-XXII. A tiraxe foi de 500 exemplares, a un peso.

58 Cf. R. Groba: «A propósito del futuro federal», Galicia, 24.2.1940, e mais a resposta de A. Castro: «Un galego inferior», Galicia, 2.3.1940. Para o contexto, cf. H. Díaz: Historia de la Federación de Sociedades Gallegas: Identidades politicas y prácticas militantes, Bos Aires, Biblos, 2007, pp. 102-05. 
xeito tépedo que a poetisa, polo feito de escribir en galego e tamén en castelán, e pola súa fondura poética, podía ben servir como exemplo da suposta convivencia da literatura galega coa castelá e, mesmo, da súa subordinación a esta última. Nas páxinas do órgano profalanxista porteño $\mathrm{Fe}$ Gallega ou do semanario Correo de Galicia, agora entregado á causa dos insurrectos, por exemplo, as alusións, sequera anecdóticas, a Rosalía estaban por completo ausentes. E, cando aparecían, era, sobre todo, para salientar, como facía o ex-galeguista e falanxista ourensán Eugenio Montes durante a súa xeira de palestras na América do Sur entre finais de 1937 e comezos de 1938, que o verso castelán de Rosalía era máis «entrañable» que a súa obra en galego, pois esta última só expresaba o «resentimiento del pueblo gallego" ${ }^{" 59}$. Rosalía en castelán era moito máis asumíbel para a nacente España nacional que a súa problemática obra en galego, chea de matices reivindicativos que non lles pracían aos sublevados.

Non foi así, porén, no caso da prensa leal á República, dos voceiros dos exiliados e das cabeceiras galeguistas. Certo é que Rosalía xamais pasou a ocupar un lugar sobranceiro como mito de loita e resistencia. Eran momentos en que as antigas iconas reivindicativas do galeguismo estaban a ser completadas cos novos símbolos, agora tamén devidos en mitos mobilizadores, da loita antifascista, nomeadamente o da Galiza mártir, impulsado sobre todo por Castelao, e as datas e efemérides a ela asociadas, como o culto á memoria de Alexandre Bóveda cada 17 de agosto dende 1942 — iniciativa de Castelao aprobada pola Irmandade Galega para lembrar a Galiza mártir_-, a conmemoración dos Mártires de Carral ou a do cabodano do plebiscito estatutario cada 28 de xuño, ás que se engadiría dende 1950 o propio culto á memoria de Castelao. Os mártires de combate caídos na Guerra Civil imperaban agora na propaganda conmemorativa, pois do seu sangue había xurdir a seiva que nutriría o país rexurdido.

Emporiso, Rosalía era un símbolo irrenunciábel para o galeguismo do exilio, como lembraba Rodolfo Prada no 1945, quen subliñaba que aquela fora igualmente un exemplo de muller combativa, que lanzou «violentos ataques» coa súa

59 «El homenaje de la colectividad gallega a nuestro camarada Eugenio Montes», Falange Española, 1.1.1938, reproducido en X. Alonso Montero e M. Villar: Guerra Civil (1936-1939) e literatura galega (textos e documentos para unhas xornadas de estudo e debate), Santiago de Compostela, Consello da Cultura Galega, 1999, p. 127. 
arma máis afiada, o verso, co que "acometió valiente y recia" ${ }^{60}$. Os tons e motivos asociados a Rosalía nas homenaxes periódicas que se lle tributaron durante as décadas de 1940 seguían a ser os xa clásicos, mais tamén presentaron algúns matices $^{61}$. Pois amais de matria e musa, a súa evocación servía para expresar como ninguén a señardade pola terra natal dos exiliados, e a súa expresión da dor e da angustia existencial era equiparada implicitamente, como facían Marcial Fernández no $1942^{62}$ ou Ramón Rey Baltar tres anos máis tarde, ás saudades dos que se vían trasterrados pola forza ${ }^{63}$. Ramón Suárez Picallo escribía dende Chile no 1943 que «Santa Rosalía» era «deidad de nuestra cabecera, en las noches, sólo alumbradas por los recuerdos y las saudades" ${ }^{\prime 4}$. O intelectual arxentino Augusto Cortina Aravena, editor da obra poética de Rosalía no país austral, expresábao igualmente dous anos despois: «Cómo sintió la tristeza de todos los destierros!"65. E Luisa Carnés escribiu unha biografía de Rosalía dende o seu exilio mexicano, editada no 1945 , onde tamén salientaba que a poetisa, sen saír da súa terra, «supo contar y llorar el dolor de los desterrados"

Dende Bos Aires, seguíanse a apoiar as actividades relacionadas co culto á memoria de Rosalía no interior de Galicia: así, periodicamente, recadáronse fondos para apoiar economicamente o labor do Patronato Rosalía de Castro, fundado en 1947 , baixo a común iniciativa dos galeguistas que seguían a protagonizar

60 R. Prada: «Rosalía y el galleguismo», reproducido en X. Alonso Montero (ed.), Galeuzca: Galiza-EuzkadiCatalunya: escolma posible $=$ ahalezko antologia $=$ tria possible $=$ antologia posible, Madrid, Akal, 1976, pp. 49-60.

61 V. Fuentes: «Vixencia e exaltación de Rosalía de Castro nos escritores galegos do exilio», Grial, 183 (2009), pp. 154-59.

62 M. Fernández: «Notas a "Follas Novas"», Saudade. Verba Galega nas Américas, 1 (25.7.1942), pp. 5-8.

63 R. Rey Baltar: «A door de Rosalía», El Orensano, 24.2.1945.

64 R. Suárez Picallo: «Historia de un libro de versos: "Follas Novas", de Rosalía de Castro» [19.12.1943], en id., La feria del mundo. Crónicas desde Chile (1942-1956), Santiago de Compostela, Consello da Cultura Galega, 2008, pp. 193-96.

65 A. Cortina: «En el jardín de Rosalía», artigo da revista Estampa reproducido en El Orensano, 25.7.1945. Vid., do mesmo autor, a edición de poesías rosalianas: Obra completa de Rosalía de Castro, Bos Aires, Espasa-Calpe, 1942, cuxo limiar introdutorio («Rosalía de Castro y su obra poética») fora xa publicado en 1930 na revista da Universidad de La Plata Humanidades (vol. XXI). Tamén se ocupou da obra de Rosalía a filóloga arxentina Alicia Santaella Murias na súa tese de doutoramento (Rosalía de Castro: vida, poética y ambiente, Bos Aires, s. ed. [Centro Gallego], 1942), defendida igualmente na Universidad de La Plata.

66 L. Carnés: Rosalía de Castro. A cita corresponde a unha dedicatoria autógrafa de Luisa Carnés (citada na edición de A. Plaza Plaza de L. Carnés: El eslabón perdido, Sevilla, Renacimiento, 2002, p. 43). 
unha resistencia cultural e mais sectores de sensibilidade rexionalista do propio aparello local franquista. Con todo, e como xa sinalamos, outros mitos en principio máis aptos para o combate, a resistencia e a mantenza do facho aceso do galeguismo resultaban máis eficaces no exilio que a sufrida Rosalía. Mesmo a figura de Curros Enríquez coñeceu unha forte reactualización, sobre todo na prensa galega de Cuba e México, como exemplo de poeta republicano, comprometido e trasterrado. Mais a poetisa seguiu a ser obxecto de homenaxes polos galeguistas porteños ao longo da década de 1950. A súa mitificación expresábase tamén na continuidade do vocabulario empregado para referirse á súa figura: Santa, Matria... Unha sorte de culto secularizado no que a figura de Rosalía se asociaba á patria ausente, encarnada (como todas as nacións) nunha figura feminina, a nai. A escritora ficou como unha referencia incontestábel da codificación da saudade, mais tamén da situación da muller, das viúvas de vivos - como expresaba no seu libro Follas novas (1880) — e da experiencia feminina fronte á emigración, sobre todo das mulleres que en Galicia ficaran. Era a nai/matria que seguía a agardar polos froitos que os seus fillos ausentes, emigrantes e exiliados, habían levarlle. E, ás veces, Castelao, pai da patria morto no desterro, era asociado a ela ${ }^{67}$. De xeito significativo, un dos premios literarios dos Xogos Froraes do Idioma Galego de agosto de 1968, organizados polos sectores galeguistas da colectividade emigrada de Bos Aires co concurso de varias decenas de asociacións galaicas, levaba o nome de Rosalía de Castro, e destinábase ao «canto á muller galega» en galego. $\mathrm{O}$ vencedor non foi outro que o poeta Celso Emilio Ferreiro, na altura emigrado en Caracas, cunha composición titulada, precisamente, "Miña matria Galicia» ${ }^{68 .}$

A actualidade da obra rosaliana, e a súa forza evocativa e simbólica, corría tamén parella a certa banalización do seu coñecemento, a unha popularidade difusa. Os seus libros de versos eran lidos por relativamente poucos e non se vendían moito. Pero algúns dos seus poemas (ou cabería dicir, mesmo, estrofas ou retrousos) máis emblemáticos si eran cońecidos e parafraseados por moitos emigrantes, como efecto dunha sorte de orballo rosaliano que a través de diferentes medios, en Galicia ou en América, conseguira callar neles. A popularidade

67 Vid., por exemplo, R. Prada: «Rosalía e Castelao», Galicia: Revista del Centro Gallego de Buenos Aires, 604

(1975), pp. 44-47.

68 VV. AA.: Xogos froraes do idioma galego, Bos Aires, Nós, 1969. 
levaba tamén consigo, porén, unha certa superficialidade na súa recepción. $\mathrm{Na}$ homenaxe anual a Rosalía de Castro celebrada perante o seu busto no Centro Galego de Bos Aires en xullo de 1964, Blanco-Amor laiábase do feito de a edición de 500 exemplares da súa antoloxía editada vinte e cinco anos denantes non se ter esgotado. Porén, sinalaba igualmente que, dalgún xeito, Rosalía estaba presente na «intraconsciencia» da maioría dos galegos emigrados: Rosalía de Castro deviñera nun mito asumido de maneira capilar por milleiros deles, malia que non todos, nin sequera a maioría, serían quen de verbalizar en que consistía a súa importancia. Talvez niso radicaba o éxito da súa recepción, que tivera lugar entre Galicia e América. Rosalía foi un bo exemplo de recepción cultural transatlántica. Velaí tamén a singularidade da súa transcendencia, galega, europea e americana. 
